Jurnal IImiah Akuntansi dan Kenangan

http://journal.stieputrabangsa.ac.id/index.php/jiak

ISSN: 2580-510X/ P-ISSN: 2548-9453

ARTICLE INFORMATION

Received October $14^{\text {th }} 2019$

Accepted December $27^{\text {th }} 2019$

Published January $24^{\text {th }} 2020$

DOI:

10.32639/jiak.v9i1.356

\section{Pengaruh Pengeluaran Konsumsi Rumah Tangga, Investasi Swasta dan Belanja Langsung Pemerintah Daerah Terhadap Pertumbuhan Ekonomi di Kabupaten Lombok Timur Tahun 2001-2017}

\author{
Padli Padli ${ }^{1}$, Hailuddin Hailuddin ${ }^{2}$, Wahyunadi Wahyunadi ${ }^{3}$ \\ 1,2,3) Universitas Mataram \\ email: Padli155@yahoo.com
}

\begin{abstract}
ABSTRAK
Penelitian ini bertujuan untuk menganalisis pengeluaran konsumsi rumah tangga, investasi swasta dan belanja langsung pemerintah daerah terhadap pertumbuhan ekonomi di Kabupaten Lombok Timur serta menganalisis variabel mana yang memberikan pengaruh dominan terhadap pertumbuhan ekonomi di Kabupaten Lombok Timur. Penelitian ini merupakan jenis penelitian kausal dengan metode kuantitatif dengan menggunakan metode analisis regresi linier berganda. Variabel terikat dalam penelitian ini pertumbuhan ekonomi, pengeluaran konsumsi rumah tangga, investasi swasta dan belanja langsung pemerintah daerah sebagai variabel bebas. Hasil penelitian menunjukan bahwa pengeluaran konsumsi rumah tangga dan investasi swasta tidak berpengaruh signifikan terhadap pertumbuhan ekonomi. Sedangkan variabel belanja langsung pemerintah daerah berpengaruh signifikan terhadap pertumbuhan ekonomi. Variabel belanja langsung pemerintah daerah mempunyai pengaruh dominan terhadap pertumbuhan ekonomi, sedangkan variabel yang paling kecil pengaruhnya terhadap pertumbuhan ekonomi yaitu variabel konsumsi rumah tangga.
\end{abstract}

Kata Kunci: Pengeluaran Konsumsi Rumah Tangga; Investasi Swasta; Belanja Langsung Pemerintah Daerah; Pertumbuhan Ekonomi

\begin{abstract}
This study aims to analyze household consumption expenditure, private investment and direct local government expenditure on economic growth in East Lombok Regency and analyze which variables have a dominant influence on economic growth in East Lombok Regency. This research is a type of causal research with quantitative methods using multiple linear regression analysis methods. The dependent variable in this study is economic growth, household consumption expenditure, private investment and direct regional government expenditure as the independent variable. The results showed that household consumption expenditure and private investment had no significant effect on economic growth. While the local government direct expenditure variable has a significant effect on economic growth. The local government direct expenditure variable has a dominant influence on economic growth, while the variable with the smallest influence on economic growth is the household consumption variable.
\end{abstract}

Keywords: Household Consumption Expenditures; Private Investment; Local Government Direct Expenditures; Economic Growth 


\section{PENDAHULUAN}

Negara KesatuanRepublik Indonesia yang terdiri atas provinsi, kabupaten/kota serta bagian-bagian daerah yang lebih kecil, pembangunannya tidak bisa dipisahkan antara pembangunan nasional dengan pembangunan daerah. Pembangunan daerah merupakan penjabaran dari pembangunan nasional dalam upaya untuk mencapai sasaran pembangunan sesuai dengan potensi, aspirasi, serta permasalahan pembangunan di daerah. Pembangunan daerah ini mencakup seluruh kegiatan pembangunan daerah dan sektoral yang berlangsung di daerah yang dilakukan oleh pemerintah dan masyarakat (Arifin, 2017:103).

Pertumbuhan ekonomi Kabupaten Lombok Timur mengalami fluktuasi. Pada tahun 2004 laju pertumbuhan ekonomi Kabupaten Lombok Timur sebesar 4,85 persen naik menjadi 5,49 pada tahun 2009 dan turun menjadi 5,01 pada tahun 2010 dan naik lagi menjadi 6,12 pada tahun 2011. Sedangkan dari tahun 2012-2017 angka laju pertumbuhan ekonomi rata-rata sebesar 5.91 persen. Meskipun pertumbuhan ekonomi Kabupaten Lombok Timur tergolong tinggi namun masih belum mampu meningkatkan pendapatan perkapita penduduknya yang di peroleh dari pembagian angka PDRB dengan penduduk Kabupaten Lombok Timur. Hal ini mengindikasikan masih rendahnya upaya pemerintah dalam hal pemberantasan kemiskinan. (BPS Kabupaten Lombok Timur, 2009:12).

Menurut Sukirno (2004:104) perhitungan PDRB dengan cara pengeluaran membedakan pengeluaran barang dan jasa yang dihasilkan dalam suatu perekonomian menjadi empat komponen, yaitu konsumsi rumah tangga, pengeluaran pemerintah, pembentukan modal sektor swasta (investasi) dan ekspor neto (ekspor-impor). Dengan demikian, pertumbuhan PDRB akan sangat dipengaruhi oleh perubahan keempat komponen tersebut.

Laju pertumbuhan konsumsi rumah tangga yang ada di Kabupaten Lombok Timur selama lima tahun, dari tahun 2012 sampai 2017. Dapat dilihat pada tabel 1.2 di bahwa. Pertumbuhan konsumsi rumah tangga tahun 2013 sebesar 3,38 persenmengalami peningkatan menjadi 4,63 persen pada tahun 2014 hal tersebut disebabkan oleh kenaikan jumlah penduduk menjadi salah satu pendorong terjadinya kenaikan pengeluaran konsumsi rumah tanggadan di sisilain didorong oleh meningkatnya pendapatan rumah tangga. Meskipun demikian, pertumbuhan konsumsi rumah tangga perlu diwaspadai mengingat terjadi penurunan pertumbuhan pada tahun 2015 sebesar 1,82 persen, hal ini disebabkan oleh menurunan daya beli masyarakat sepanjang tahun 2015 yang dipengaruhi oleh naiknya harga beras di awal tahun, naiknya harga beras di awal tahun bisa mempengaruhi kemampuan daya beli,utamanya untuk masyarakat kurang mampu. Sedangkan pertumbuhan konsumsi rumah tangga tahun 2017 lebih tinggi bila dibandingkan dengan tahun 2016 yang hanya mencapai pertumbuhan sebesar 1,95 persen yang disebabkan karena adanya dorongan bulan puasa dan tingkatinflasi yang relatif terjaga juga memberikan dampak positif terhadap pertumbuhan konsumsi rumah tangga.

Selain konsumsi rumah tangga, Pembentukan Modal Tetap Domestik Bruto (PMTB) yang secara akumulatif memiliki nilai output atau produksi yang lebih besar dan selanjutnya dapat mendorong meningkatnya pendapatan masyarakat. Apabila akumulasi dan akslarasi nilai PMTB ini terwujud secara memedai maka dapat dipastikan perekonomian daerah akan terus berkembang pesat dengan laju pertumbuhan yang tinggi pula.

Perekembangan pengeluaran pemerintah daerah yang diukur dari besarnya belanja langsung dan belanja tidak langsung pemerintah daerahKabupaten Lombok Timur dengan rata-rata realisasi belanja langsung dari tahun 2001-2017 yang digunakan untuk investasi guna mencapai sasaran-sasaran program yang telah ditetapkan ternyata lebih kecil Rp 306.229,023 juta dibandingkan dengan rata-rata realisasi belanja tidak langsung sebesar Rp 667.338,036 juta yang digunakan untuk pelaksanaan untuk berbagai program dan kegiatan pemerintahaan yang bersifat operasional dan peningkatan jangkauan mutu pelayanan terhadap masyarakat (BPS Kabupaten Lombok Timur, 2009:23) . Bila dilihat dari proporsi realisasi belanja langsung terhadap total realisasi belanja sebesar $34,84 \%$ lebih kecil bila dibandingkan dengan proporsi realisasi belanja tidak langsung yang hanya sebesar $65,15 \%$. Rata-rata realisasi maupun proporsi realisasi belanja langsung yang relatif lebih kecil bila dibandingkan dengan realisasi belanja tidak langsung menunjukkan 
bahwa alokasi anggaran sebagian besar digunakan untuk kepentingan yang bersifat konsumtif. Keadaan ini menyebabkan realisasi belanja langsung daerah yang kecil belum mampu mendorong tingkat pertumbuhan ekonomi di Kabupaten Lombok Timur secara signifikan.

Dari paparan di atas penulis merasa tertarik untuk menelitipengaruh pengeluaran konsumsi rumah tangga, investasi swasta dan pengeluaran langsung pemerintah daerah terhadap pertumbuhan ekonomi di Kabupaten Lombok Timur tahun 2001.-2017

\section{KAJIAN LITERATUR}

\section{Konsumsi Rumah Tangga}

Konsep konsumsi, yang merupakan konsep yang di Indonesiakan dari kata bahasa inggris "consumption" berati pembelanjaan yang di lakukan oleh rumah tangga ke atas barang-barang akhir dan jasa dengan tujuan untuk memenuhi kebutuhan dari orang yang melakukan pembelanjaan tersebut. Pembelanjaan masyarakat ke atas makanan, pakaian dan barang-barang kebutuhan mereka yang lain digolongkan ke atas pengeluaran konsumsi (Sukirno, 2005:31).

\section{Investasi Swasta}

Mankiw (2003:12) menjelaskan investasi adalah pembelian atas berbagai peralatan modal, persediaan dan struktur bisnis, investasi juga mencakup pembelian rumah baru (meskipun dilakukan oleh rumah tangga). Pembentukan modal tetap bruto suatu daerah adalah pengadaan, pembuatan dan pembelian barang modal baru dari dalam daerah dan termasuk juga barang modal dari dalam daerah atau wilayah dan termasuk juga barang modal baru atau bekas dari luar daerah atau wilayah yang digunakan sebagai alat berproduksi. Pengertian barang modal itu sendiri adalah barang-barang yang mempunyai umur pemakaian satu tahun atau lebih dalam pengertian barang-barang tersebut di gunakan sebagai alat tetap dalam peroses produksi.

\section{Pengeluaran Pemerintah}

Menurut Guritno (2014:171) pengeluaran pemerintah dari waktu ke waktu semakin meningkat karena semakin bertambahnya kegiatan pemerintah yang memerlukan pembiayaan. Adolf Wagner menyebutnya dengan hukum makin meningkatnya kegiatan negara atau hukum makin meningkatnya pengeluaran negara. Peningkatan pengeluaran negara dalam arti relatif yaitu membandingkan pengeluaran negara dengan produk nasional bruto dan atau membandingkan dengan pengeluaran sektor swasta.

\section{Pertumbuhan Ekonomi}

Pertumbuhan ekonomi merupakan suatu perubahan tingkat kegiatan ekonomi yang berlangsung dari tahun ke tahun. Untuk menghitung tingkat pertumbuhan ekonomi harus dibandingkan dengan pendapatan nasional berbagai tahun yang dihitung berdasarkan atas harga konstan (Sukirno 2004:443). Jadi perubahan dalam nilai pendapatan hanya semata-mata disebabkan oleh suatu perubahan dalam suatu tingkat kegiatan ekonomi. Laju pertumbuhan ekonomi suatu daerah dapat dihitung melalui indikator perkembangan PDRB dari tahun ke tahun. Suatu perekonomian dikatakan baik apabila tingkat kegiatan ekonomi masa sekarang lebih tinggi dari pada yang dicapai pada tahun-tahun sebelumnya.

\section{METODE}

\section{Klasifikasi Variabel}

a) Variabel dependen merupakan variabel yang nilainya ditentukan oleh besar kecilnya nilai variabel independen. Pada penelitian ini variabel dependennya adalah pertumbuhan ekonomi (Y). 
b) Variabelindependenadalah variabel yang mempengaruhi nilai variabel dependen. Dalam penelitian ini variabel independennya adalah pengeluaran konsumsi rumah tangga $\left(\mathrm{X}_{1}\right)$, investasi swasta $\left(X_{2}\right)$ dan pengeluaran langsung pemerintah $\left(X_{3}\right)$.

\section{Teknik Pengumpulan Data}

Teknik pengumpulan data yang digunakan untuk mencapai tujuan penelitian ini sepenuhnya diperoleh melalui teknik dokumentasi. Teknikdokumentasi adalah mencari data mengenai hal-hal atau variabel yang berupa tulisan, gambar atau karya-karya monumental dari seseorang (Arikunto, 2002:80).

\section{Teknik Analisis Data}

Analisis regresi pada dasarnya adalah studi mengenai ketergantungan suatu variabel dependen dengan satu atau lebih variabel independen dengan tujuan untuk mengestimasi dan memperediksi rata-rata populasi atau nilai rata-rata variabel dependen berdasarkan nilai variabel independen yang diketahui (Kuncoro, 2007:76).

$Y=f\left(X_{1}, X_{2}, X_{3}\right)$

Dalam model penelitian ini logritma yang digunakan adalah dalam bentuk log-linier (log). Sehingga persamaan menjadi sebagai berikut:

$$
\log Y=b_{0}+b_{1} \log X_{1}+b_{2} \log X_{2}+b_{3} \log X_{3}+\mu
$$

Keterangan:

$\log Y \quad$ : pertumbuhan ekonomi atau laju PDRB rill

bo : Konstanta

$b_{1}, b_{2}, b_{3}$ : Koefesien regresi

$\log \mathrm{X}_{1} \quad$ : Konsumsi rumah tangga

$\log X_{2} \quad$ : Investasi swasta

$\log X_{3} \quad$ : Pengeluaran pemerintah daerah

$\mu \quad$ : Standar error

\section{Hipotesis}

a) Diduga konsumsi rumah tangga, investasi swasta dan pengeluaran langsung pemerintah daerah berpengaruh signifikan terhadap pertumbuhan ekonomi di Kabupaten Lombok Timur tahun 2001-2017

b) Diduga investasi swasta mempunyai pengaruh dominan terhadap pertumbuhan ekonomi di Kabupaten Lombok Timur tahun 2001-2017

\section{HASIL DAN PEMBAHASAN}

\section{Hasil Penelitian}

\section{Pengeluaran Konsumsi Rumah Tangga}

Konsumsi rumah tangga cenderung mengalami fluktuatif. Pertumbuhan tertinggi dicapai pada tahun 2007 sebesar 6,34 persen disebabkan oleh Menurunnya suku bunga regional dan membaiknya dukungan pembiayaan perbankan maupun lembaga-lembaga pembiayaan konsumen yang menjadi faktor penggerak pertumbuhan konsumsi rumah tangga, meningkatnya pertumbuhan konsumsi rumah tangga padatahun 2007juga disebabkan oleh membaiknya pendapatan masyarakat seiring membaiknya sektor sektor ekonomi Lombok Timur yang padat karya (sektor perdagangan dan sektor pendukung pariwisata, seperti penyediaan akomodasi). Hal ini merupakan indikasi positif terhadap membaiknya daya beli masyarakat dan melambat hingga 1,95 persen pada tahun 2016 yang disebabkan olehturunnya daya beli masyaakat yang disebabkan oleh oleh rendahnya pendapatan. Meskipun demikian, rata-rata pertumbuhan konsumsi rumah tangga pada tahun 2001-2017 masih berada di empat persen yang 
didukung oleh jumlah kelompok pendapatan menengah (middle income class) yang relatif besar dan tingkat inflasi yang stabil.

\section{Investasi Swasta}

Pada periode tahun 2001-2017, pertumbuhan investasi rata-rata mencapai 4,55 persen per tahun. Pertumbuhan investasi pada tahun 2003 yang hanya tumbuh sebesar 4,32 persen dan turun pada tahun 2004 menjadi 3,90 persen. Penurunan tersebut disebabkan oleh penurunan investasi pada barang modal jenis kendaraan akibat turunnya angka penjualan mobil serta disebabkan oleh turunnya impor barang modal. Ditahun 2015, pertumbuhan investasi mulai meningkat secara signifikan terutama didorong oleh peningkatan investasi untuk infrastruktur, baik yang pelaksanaannya dilakukan oleh Pemerintah daerah, pihak swasta maupundalambentukkerja sama pemerintah daerah dan badan usaha. Pertumbuhan investasi tertinggi terjadi pada tahun 2016, hal ini disebabkanoleh pembangunan sarana dan prasarana fisik di Kabupaten Lombok Timur terutamapembangunan perumahan dan pusat-pusat perdagangan serta tempat ibadah serta di dukung oleh kebijakan perbaikan iklim investasi.

\section{Pengeluaran Pemerintah}

Anggaran daerah merupakan rencana keuangan yang menjadi dasar dalam pelaksanaan penyelengaraan publik. Di Indonesia, dokumen anggaran disebut anggaran pendapatan belanja daerah (APBD), baik untuk provinsi maupun kabupaten dan kota.Anggaran pendapatan belanja daerah pada hakekatnya merupakan salah satu instrumen kebijakan yang dipakai sebagai alat untuk pelayanan umum dan kesejahteraan masyarakat di suatu daerah. Di dalam APBD tercermin kebutuhan masyarakat dengan memperhatikan potensi dan sumber-sumber kekayaan daerah (UU Keuangan Negara, 2002).

Pengeluaran pemerintah daerah cenderung fluktuatif dengan pertumbuhan tertinggi sebesar 193,32 persen pada tahun 2003. Hal ini disebabkan sebagian besar belanjalangsung digunakan untuk belanja pegawai.Pengalokasian belanja pegawai yang lebih besar di bandingkan belanja modal dan belanja barang bukan berarti pelayanan terhadap masyarakat menjadi kurang optimal. Pemerintah daerah terus berupaya untuk meningkatkan efisiensi dan efektivitas belanja daerah agar memiliki dampak yang besar terhadap perekonomian melalui alokasi pada belanja produktif. Penurunan belanja langsung pemerintah daerah pada tahun 2007-2008 diakibatkan adanya penurunan belanja modal dan belanja pegawai.Pada tahun2016, pengeluaran pemerintah daerah tumbuh sebesar 59.29 persen, lebih tinggi dibandingkan tahun-tahun sebelumnya yang didorong oleh kenaikan realisasi dari belanja barang dan belanja pegawai yang cukup signifikan dibandingkan tahun-tahun sebelumnya. Perbaikan ini juga didukung oleh percepatan penyerapan anggaran yang telah dilakukan oleh pemerintah daerah sehingga mendorong realisasi belanja yang lebih baik.

\section{Pertumbuhan Ekonomi}

Selama periode 2001-2017 pertumbuhan ekonomi Kabupaten Lombok Timur mengalami fluktuatif, dimana pada tahun 2001pertumbuhan ekonomi Kabupaten Lombok Timur sebesar Rp 2,01 persen meningkat menjadi Rp 5,49persen pada tahun 2008. Pertumbuhan ekonomi mulai melambat pada tahun 2014 sebesar 4,93 persen. Faktor yang dianggap berpengaruh terhadap Perlambatan pertumbuhan ekonomian dipengaruhi oleh konsumsi rumah tangga yang belum pulih. Daya beli masyarakat masih lemah sebagai konsekuensi dari menurunnya pendapatan dan inflasi bahan makanan yang masih cukup tinggi. Serta penurunan perdagangan akibat perlemahan permintaan ekonomi regional. Pada tahun 2017 perekonomian Kabupaten Lombok Timur mulai membaik di tandai dengan meningkatnya pertumbuhan ekonomi sebesar 6,25 persen.

Membaiknya pertumbuhan ekonomi pada tahun 2017 ditopong oleh sektor pertanian menjadi salah satu penyumbangutama pertumbuhan ekonomi di Lombok Timur dengan kontribusi sebesar 28,15 persen. Pertumbuhandi sektor pertanian didorong oleh peningkatan produksi komoditas-komoditaspertanian yang termasuk kedalam Tanaman Bahan Makanan terutama Padi, Jagung,dan Kedelai. 


\section{Hasil Analisis Data}

\section{Hasil Pengujian Regresi}

$Y=7.152+0.106 X_{1}+3.946 X_{2}+4.881 X_{3}$

Dari persamaan regresi yang didapatmaka dapat diinterpretasi sebagai berikut:

a) Konstanta atau koefesien ßo sebesar 7.152 menunjukkan bahwa apabila konsumsi rumah tangga, investasi swasta dan belanja langsung pemerintah daerah dianggap konstan maka pertumbuhan ekonomi akan naik sebesar 7.152 persen.

b) Variabel pengeluaran konsumsi rumah tangga mempunyai pengaruh yang positif terhadap pertumbuhan ekonomi dengan nilai koefesien regresi sebesar 0.106 yang apabila pengeluaran konsumsi rumah tangga naik sebesar 1 rupiah maka pertumbuhan ekonomi akan meningkat sebesar 0.106 persen dengan asumsi bahwa variabel-variabel lain dianggap konstan. Dengan adanya pengaruh yang positif ini, berarti bahwa antara pengeluaran konsumsi rumah tangga dan pertumbuhan ekonomi mempunyai hubungan yang searah.

c) Variabel investasi swasta mempunyai pengaruh yang positif terhadap pertumbuhan ekonomi di Kabupaten Lombok Timur yang dilihat dari nilai koefesien regresi sebesar 3.946 yang apabila investasi swasta naik sebesar 1 rupiah maka pertumbuhan ekonomi akan meningkat sebesar 3.9460 persen dengan asumsi bahwa variabel-variabel lain dianggap konstan. Dengan adanya pengaruh yang positif ini, bererti antara investasi swasta dengan pertumbuhan ekonomi mempunyai hubungan yang searah.

d) Variabel belanja langsung pemerintah daerah mempunyai pengaruh yang positif terhadap pertumbuhan ekonomi yang dilihat dari nilai koefesien regresinya sebesar 4.881 yang apabila belanja langsung pemerintah daerah naik sebesar 1 rupiah rupiah maka pertumbuhan ekonomi akan meningkat sebesar 4.881 persen dengan asumsi bahwa variabel-variabel lain dianggap konstan. Dengan adanya pengaruh yang positif ini, berarti bahwa antara variabel belanja langsung pemerintah daerah mempunyai hubungan yang searah.

\section{Uji Asumsi Klasik}

\section{Uji Multikolineritas}

Tabel 1. Uji Multikolinearitas dengan Deteksi Klien

\begin{tabular}{cccc}
\hline Variabel & $\mathbf{R}^{2}$ Model & $\mathbf{R}^{2}$ Parsial & Keterangan \\
\hline $\mathrm{R}^{2} \times 1,2,3$ & 0.718 & 0.705 & Bebas Multikolinearitas \\
$\mathrm{R}^{2} \times 2,1,3$ & 0.718 & 0.709 & Bebas Multikolinearitas \\
$\mathrm{R}^{2}{ }_{3,1,2}$ & 0.718 & 0.097 & Bebas Multikolinearitas \\
\hline
\end{tabular}

Sumber: Data diolah

Berdasarkan tabel 1, menunjukkan bahwa model regresi tidak mengalami gangguan multikolinearitas, karena semua nilai $\mathrm{R}^{2}$ parsial lebih kecil dari nilai $\mathrm{R}^{2}$ model.

\section{Uji Heterokedastisitas}

Tabel 2. Hasil Uji Park

\begin{tabular}{ccccc}
\hline Variabel & Sig & Alpha & t-Hit & t-Tabel \\
\hline Konsumsi & 0.94 & 0,05 & -0.06 & 2,16 \\
Investasi Swasta & 0.74 & 0,05 & -0.33 & 2,16 \\
Belanja Langsung & 0.21 & 0,05 & 1.28 & 2,16 \\
\hline Sumber: Data diolah & & & &
\end{tabular}

Berdasarkan hasil pengujian heterokedastisitas dengan uji Park terlihat bahwa semua variabel bebas tidak signifikan dengan variabel terikat yang dilihat dari nilai Sig yang lebih besar dari 0,05. Bila dilihat dari nilai 
t-hitung maka semua nilai t-hitung < t-tabel atau tidak signifikan, hal ini menandakan bahwa didalam model tersebut tidak terjadi masalah heterokedastisitas.

\section{Uji Autokorelasi}

Uji autokorelasi bertujuan untuk menguji apakah dalam suatu model regresi linier ada korelasi antara variabel pengganggu (residual) pada periode $\mathrm{t}$ dengankesalahan pada priode $\mathrm{t}-1$ (sebelumnya). Uji autokorelasi dilihat dari Durbin Waston statistik. Dari hasil pengolahan data terlihat tidak ada masalah autokorelasi didalam model yang dibuat. Hasil uji autokorelasi menghasilkan nilai DW statistik sebesar 1.999. Nilai tabel dengan menggunakan alpha 5\% jumlah sampel 17 dan jumlah variabel independen 3 , maka dari tabel 4Durbin Watson akan didapat nilai $\mathrm{dl}=0,897$ dan $\mathrm{du}=1,710$, menunjukkan bahwa nilai DW statistik sebesar 1,823 dan berada pada daerah bebas autokorelasi. Sehingga dapat disimpulkan bahwa model regresi bebas dari autokorelasi.

\section{Uji Normalitas}

Uji normalitas bertujuan untuk menguji apakah dalam sebuah model regresi, variabel dependen, variabel independen atau keduanya mempunyai distribusi normal atau tidak. Model regresi yang baik adalah distribusi data normal atau mendekati normal. Untuk menguji normalitas data ini menggunakan analisis $J$ - $B$ tes (Firmansyah, 2008:41).

Tabel 3. Hasil Uji Normalitas J-B

\begin{tabular}{cccc}
\hline Variabel & Probability & J-B & Kesimpulan \\
\hline Residual & 0,5149 & 1,327 & Normal \\
\hline
\end{tabular}

Sumber: Data diolah

Pada hasil pengujian Jarque Bear (J-B test) terlihat bahwa nilai Jarque Bear (J-B test) lebih kecil dari $\chi^{2} 23,685$. Oleh karenanya nilai Jarque Bera (J-B test) lebih kecil dari nilai tabel maka dapat disimpulkn data yang digunakan berdistribusi normal (Firmansyah, 2008:41).

\section{Uji Hipotesis}

\section{Koefesien Determinasi $\left(R^{2}\right)$}

Dari perhitungan nilai Rsquare adalah 0.7184 . Hal ini berarti 71.84 persen perekonomian Kabupaten Lombok Timur dapat dijelaskan oleh ketiga variabel independen diatas, sedangkan sisanya sebesar 28,1557 persen dijelaskan oleh variabel lain diluar model yang dibuat.

\section{Uji Individual (Uji t)}

Pada uji statistik secara parsial dengan nilai t tabel pada $d f=(n-k)$, dimana $n$ adalah jumlah sampel dan $k$ adalah jumlal variabel independen termasuk konstanta. Untuk menguji koefesien regresi secara individual dari masing-masing variabel bebas akan diuji sebagai berikut:

a) Pengeluaran Konsumsi Rumah Tangga

Dari hasil perhitungan regresi linier berganda diperoleh nilai $t$ hitung untuk pengeluaran konsumsi rumah tangga sebesar 0.0687 dan pada t tabel dengan tingkat signifikan sebesar 95 persen $(\alpha=5 \%), d f=13$ diperoleh 2,16. Terlihat bahwa nilai t hitung lebih kecil dari nilai t tabel. Dapat disimpulkan bahwa pengeluaran konsumsi rumah tangga tidak berpengaruh signifikan terhadap pertumbuhan ekonomi di Kabupaten Lombok Timur.

b) Investasi Swasta

Dari hasil perhitungan regresi linier berganda diperoleh nilai t hitung untuk investasi swasta sebesar1.9909 dan pada t tabel dengan tingkat signifikan sebesar 95 persen $(\alpha=5 \%)$, df $=13$ diperoleh 2,16. terlihat bahwa nilai t hitung lebih kecil dari nilai t tabel. Dapat disimpulkan bahwa investasi swasta tidak berpengaruh signifikan terhadap pertumbuhan ekonomi di Kabupaten Lombok Timur. 
c) Belanja Langsung Pemerintah

Dari hasil perhitungan regresi linier berganda diperoleh nilai t hitung untuk belanja lagsung pemerintah sebesar3.1400 dan pada t tabel dengan tingkat signifikan sebesar 95 persen $(\alpha=5 \%)$, $\mathrm{df}=13$ diperoleh 2,16. terlihat bahwa nilai t hitung lebih besar dari nilai t tabel. Dapat disimpulkan bahwa belanja langsung pemerintah daerah berpengaruh signifikan terhadap pertumbuhan ekonomi di Kabupaten Lombok Timur.

\section{Uji Simultan (Uji F)}

Uji statistik secara simultan ditunjukkan oleh perbandingan nilai $\mathrm{F}$ hitung dengan $\mathrm{F}$ tabel. Nilai $\mathrm{F}$ tabel dengan $d f=(k-1, n-k)$, dengan drajat kepercayaan sebesar 95 persen, adalah $F_{0.05,3,13}$ sebesar 3.41. pada tabel 4.5 diatas terlihat $F$ hitung 11.0572adalah jauh lebih besar dari F tabelnya. Ini berarti ketiga variabel independen signifikan terhadap pertumbuhan ekonomi di Kabupaten Lombok Timur.

\section{Pembahasan Hasil}

Ketidaksignifikannya variabel konsumsi rumah tangga terhadap pertumbuhan ekonomi disebabkan oleh menurunya pendpatan masyarakat yang mengakibatkan menurunnya daya beli masyarakat terhadap barang-barang yang dibutuhkan baik dalam bentuk makanan maupun non makanan, hal tersebut akan mempengaruhi pola konsumsi masyarakat. Pola konsumsi masyarakat memang sangat tergantung pada sumber pendapatan rumah tangga, semakin tinggi pendapatan rumah tangga, semakin banyak pula kebutuhan yang akan dapat dipenuhi. Perilaku konsumen pada dasarnya memiliki berbagai kombinasi konsumsi beberap barang yang dapat memaksimumkan kepuasannya.

Beberapa ahli ekonomi mengungkapkan bahwa makanan dapat dijadikan indikator dalam menilai tingkat kesejahteraan ekonomi masyarakat. Dewi (2018:129) menyatakan bahwa semakin tinggi kesejahteraan masyarakat suatu daerah, maka proporsi pengeluaran untuk makanan penduduknya akan semakin kecil, demikian sebaliknya. Pengeluaran makanan rumah tangga akan meningkat sejalan dengan meningkatnya pendapatan, akan tetapi proporsi pengeluaran makanan tersebut dari total pendapatan akan menurun, fenomena ini yang dikenal dengan Hukum Engel (Noor, 2007:129).

Dengan terjadinya hal tersebut maka akan mengakibatkan menurunnya tingkat kesejahteraan masyarakat, khususnya bagi masyarakat yang tidak mempunyai pendapatan.

Tidak Signifikannya nilai investasi swasta disebabkan tidak produktifnya jumlah investasi dalam bentuk bangunan-bangunan toko, hotel, jasa perusahan dan restoran yang ada, sehingga hal tersebut akan mengakibatkan rendahnya nilai tambah yang di hasilkan oleh investasi yang bersangkutan dan pada akhirnya akan berdampak pula pada rendahnya pertumbuhan ekonomi.

Hasil penelitian ini sejalan dengan hasil penelitian yang dilakukan oleh Anwar Ramli (2013) yang melakukan penelitian dengan judul peran konsumsi, investasi dan pengeluaran pemerintah terhadap pertumbuhan ekonomi di Sulawesi Selatan yang menyatakan bahwa investasi tidak berpengaruh secara signifikan terhadap pertumbuhan ekonomi di Sulawesi Selatan. Dalam temuan penelitiannya pemerintah daerah diharapkan mengeluarkan kebijakan baru yang dapat mendorong investasi di daerah baik investor domestik maupun investor asing, sehingga pemerintah dapat meningkatkan pertumbuhan ekonomi daerah. Dalam hal ini peran investor domestik dan asing perlu didorong oleh peningkatan situasi investasi yang kodusif, pembentukan unit layanan terpadu untuk kemudahan penciptaan layanan dan izin usaha investasi.

Signifikannya pengeluaran langsung pemerintah daerah terhadap pertumbuhan ekonomi disebabkan oleh semakin meningkatnya jumlah Penerimaan Asli Daerah (PAD) yang berasal dari berbagai sumber seperti yang berasal dari pajak daerah, retribusi daerah, lain-lain pendapatan yang sah dan hasil perusahaan milik daerah sehingga penerimaan-penerimaan tersebut digunakan oleh pemerintah untuk membiayai segala kegiatan yang dilakukan oleh pemerintah baik itu kegiatan yang bersifat tidak langsung maupun kegiatan yang bersifat langsung. Seperti pengeluaran untuk membiayai gaji pegawai, belanja barang, biaya perjalanan dinas, membangun dan memperbaiki infrastuktur, menyediakan fasilitas 
pendidikan dan kesehatan. Menurut Rustiono (2006) pengeluaran pemerintah akan meningkat seiring dengan peningkatan kegiatan perekonomian suatu daerah.

\section{SIMPULAN}

Pengeluarankonsumsi rumah tangga tidak berpengaruh signifikan namun berpengaruh positif terhadap pertumbuhan ekonomi dengan nilai koefesien regresi konsumsi rumah tangga adalah 0.008278 dengan nilai t-hitung sebesar 0.338767 yang berarti bahwa pengeluaran konsumsi rumah tangga tidak berpengaruh signifikan terhadap pertumbuhan ekonomi.

Investasi swasta berpengaruh tidak signifikan terhadap pertumbuhan ekonomi dengan nilai koefesien regresi sebesar 0.0308 dengan nilai t-hitung sebesar 1.5534 yang berarti variabel investasi swasta berpengaruh tidak signifikan dan positif terhadap pertumbuhan ekonomi.

Pengeluaran langsung pemerintah berpengaruh siginfikan dan positif terhadap pertumbuhan ekonomi dengan nilai koefesien regresi sebesar 0.0525dengan nilai t-hitung sebesar 2.5021 yang berarti bahwa pengeluaran langsung pemerintah berpengaruh signifikan dan positif terhadap pertumbuhan ekonomi.

\section{REFERENSI}

Amalia, F. (2012). Penentuan sektor unggulan perekonomian wilayah Kabupaten Bone Bolango dengan pendekatan sektor pembentuk PDRB. Etikonomi, 11(2).

Amin, S. B. (2011). Causal relationship between consumption expenditure and economic growth in Bangladesh. World, 1(2), 158-169.

Anggraini, Y., \& Puranto, H. B. (2010). Anggaran Berbasis Kinerja. Penyusunan APBD Secara Komprehensif. Yogyakarta: Unit Penerbit Dan Percetakan Sekolah Tinggi Ilmu Manajemen YKPN.

Arikunto, S. (2002). Prosedur Studi Suatu Pendekatan Praktek. Jakarta: PT. Rineka Cipta.

Arsyad, L. (2004). Ekonomi Pembangunan dan Perencanaan Pembangunan. Edisi Keempat. STIE YKPN. Yogyakarta.

Aziz, R. N. A. R., \& Azmi, A. (2017). Factors affecting gross domestic product (GDP) growth in Malaysia. International Journal of Real Estate Studies, 11(4), 61-67.

Badan Pusat Statistik. (2009), PDRB Kabupaten Lombok Timur Menurut Lapangan Usaha dan Penggunaan Tahun 2005-2009

Badan Pusat Statistik. (2009-2012) Provinsi Nusa Tenggara Barat Dalam Angka

Badrudin, R. (2012). Pengaruh Desentralisasi Fiskal Terhadap Belanja Modal, Pertumbuhan Ekonomi, Dan Kesejahteraan Masyarakat Kabupaten/Kota Di Provinsi Jawa Tengah (Doctoral dissertation, UNIVERSITAS AIRLANGGA).

Daryanto, A., \& Hafizrianda, Y. (2012). Model-Model Kuantitatif untuk Perencanaan Pembangunan Ekonomi Daerah. Konsep dan Aplikasi. Bogor: IPB Press. HIm, 31-47.

Depertemen Keuangan RI. (2007) Nota Keuangan Beserta Anggaran Pendapatan dan Belanja Negara. Depkeu Jakarta.

Depertemen Keuangan RI. (2017) Nota Keuangan Beserta Anggaran Pendapatan dan Belanja Negara. Depkeu Jakarta.

Depertemen Keuangan RI. (2017) Nota Keuangan Beserta Rencana Anggaran Pendapatan dan Belanja Negara. Depkeu Jakarta. 
Djalal, N., \& Usman, H. (2006). Pendekatan populer dan praktis ekonometrika untuk analisis ekonomi dan keuangan. Jakarta: Lembaga Penerbit Fakultas Ekonomi Universitas Indonesia.

Due, J. F., Friedlaender, A. F., \& Sitompul, R. (1984). Keuangan negara: perekonomian sektor publik. Penerbit Erlangga.

Firdaus, M. (2004). Ekonometrika Suatu Pendekatan Aplikatif. Jakarta: Bumi Aksara.

Firmansyah, M. (2008). Ekonometrika: Aplikasi Regresi Linier, pooling Analysis dan Uji Kausalitas.

Ghozali, I. (2006). Aplikasi analisis multivariate dengan program SPSS.

Gujarati, D., \& Porter, D. C. (2004). Basic Econometrics, 2004. Editura McGraw-Hill, 858.

Hasan, I. (2003). Pokok-pokok materi statistik 2. Jakarta: Bumi Aksara.

Jhingan, M. L. (2002). Ekonomi Pembangunan dan Perencanaan. cetakan kesembilan. diterjemahkan oleh D. Guritno. PT. Raja Grafindo Persada Jakarta.

Jumadi, M. P., Ghozali, M., \& Khusaini, M. (2013). The Impact of Fiscal Decentralization on Local Economic Development in East Java. IOSR Journal of Humanities and Social Science, 13(1), 01-07.

Kuncoro, M. (2007). Metode Kuantitatif Teori dan Aplikasi untuk Bisnis dan Aplikasi. UPP STIM YKPN Yogyakarta.

Kuncoro, M. (2010). Dasar-dasar Ekonomika Pembangunan. Yogyakarta: UPP STIM YKPN.

Mangkoesoebroto, G. (2001). Ekonomi publik. BPFE, Yogyakarta.

Mankiw, N. G. (2006). Pengantar ekonomi edisi kedua. Jakarta: Erlangga.

Mayasari, D., Satria, D., \& Noor, I. (2018). Analisis Pola Konsumsi Pangan Berdasarkan Status IPM di Jawa Timur. Jurnal Ekonomi dan Pembangunan Indonesia, 18(2), 191-213.

Nanga, M. (2001). Makro Ekonomi Teori, Masalah dan Kebijakan Edisi Pertama. Jakarta: PT RajaGrafindo Persada.

Perdagangan, K. (2013). Laporan akhir analisis dinamika konsumsi pangan masyarakat Indonesia. Badan Pengkajian Dan Pengembangan Kebijakan Perdagangan.

Purba, A. (2006). Analisis Faktor-Faktor yang Mempengaruhi Pertumbuhan Ekonomi di Kabupaten Simalungun (Master's thesis).

Purbadharmaja, I. B. P. (2006). Implikasi Variabel Pengeluaran dan Investasi Terhadap Pertumbuhan Ekonomi Propinsi Bali. Buletin Studi Ekonomi, 11(1), 79-91.

Rahardja, P., \& Manurung, M. (2008). Teori Ekonomi Makro: Suatu Pengantar, Edisi Keempat. Buku Seri Teori Ekonomi, Lembaga Penerbit Fakultas Ekonomi Universitas Indonesia.

Raharjo, A. (2006). Pengaruh Pengeluaran Pemerintah, Investasi Swasta dan Angkatan Kerja Terhadap Pertumbuhan Ekonomi Tahun 1982-2003 (Studi Kasus di Kota Semarang) (Doctoral dissertation, Program Pascasarjana Universitas Diponegoro).

Ramli, A., \& Andriani, A. A. (2013). The Effects of Consumption, Private Investment, and Government Expenditures on Economic Growth in South Sulawesi, Indonesia. Journal of Economics and Sustainable Development, 4(14), 145-153.

Reksoprayitno, S. (2000). Ekonomi Makro (Pengantar Analisis Pendapatan Nasional), Edisi Kelima, Cetakan Kedua. Liberty, Yogyakarta.

Riduwan, M. B. A. (2010). Metode dan teknik menyusun tesis. Bandung: Alfabeta. 
Ridzuan, A. R., Razak, M. I., Ibrahim, Z., Halim, A., Noor, M., \& Ahmed, E. M. (2014). Household Consumption, Domestic Investment, Government Expenditure and Economic Growth: New Evidence from Malaysia. Journal of Scientific Research \& Reports JSRR, 3(17), 2373-2381.

Rustiono, D. (2008). Analisis pengaruh investasi, tenaga kerja, dan pengeluaran pemerintah terhadap pertumbuhan ekonomi di Propinsi jawa tengah (Doctoral dissertation, program Pascasarjana Universitas Diponegoro).

Saleh, S. (2001). Statistik Induktif. Yogyakarta: UPP AMP YKPN.

Sjafii, A. (2009). Pengaruh Investasi fisik dan investasi pembangunan manusia terhadap pertumbuhan ekonomi Jawa Timur 1990-2004. Journal of indonesian applied economics, 3(1).

Sukartini, N. M., \& Saleh, S. (2012). Pengujian Hukum Wagner dalam Perekonomian Indonesia Kajian Pengeluaran Pemerintah Pusat dan Pemerintah Provinsi. Jurnal Bisnis dan Ekonomi, 19(1).

Sukirno, S. (2000). Makroekonomi Modern: perkembangan pemikiran dari klasik hingga keynesian baru. Jakarta: Raja Grafindo Persada.

Sukirno, S. (2004). Makro Ekonomi Teori Pengantar Edisi Ketiga. Jakarta: Raja Grafindo Persada.

Suliyanto, D. (2011). Ekonometrika Terapan: Teori dan Aplikasi dengan SPSS. Penerbit Andi: Yogyakarta.

Suparmoko, M. (2003). Keuangan Negara, Dalam Teori dan Praktek, Edisi 5. Yogyakarta: BPFE.

Tarigan, R. (2009). Ekonomi Regional Teori dan Aplikasi Edisi Revisi. Jakarta: PT Bumi Aksara.

Todaro, M. P. (2006). Pembangunan Ekonomi: Di Dunia Ketiga Edisi 9, Jakarta: Penerbit Erlangga. Alih Bahasa Drs. Haris Munandar.

Yuliarmi, N. (2008). Pengaruh Konsumsi Rumah Tangga, Investasi dan Pengeluaran Pemerintah Terhadap PDRB Propinsi Bali. Bulletin Studi Ekonomi, 13(2). 